\title{
解 説 $(\mathbf{3})$ \\ 表面敏感 EXAFS によるヘテロ接合界面の評価
}

\author{
大 柳 宏之 \\ 䉓子技術総合研究所 干305つくば市概園 1-1-4 \\ (1988 年 9 月:30日 受理)
}

\section{Characterization of Hetero-Interfaces by Surface-Sensitive EXAFS}

\author{
Hiroyuki OYANAGI
}

Electrotechnical Laboratory 1-1-4, Umezono, Tsukuba-shi, Ibaraki 305

(Received September 30, 1988)

\begin{abstract}
Structural characterization technique of hetero-interfaces using surface-sensitive EXAFS is reviewed. Principles and experimental techniques are briefly described. Results of application to structural studies of $\mathrm{Si} / \mathrm{Ge} / \mathrm{Si}(100)$ hetero-interfaces perepared by molecular beam epitaxy (MBE) are reported. The formation of ordered $\mathrm{Si} / \mathrm{Ge} / \mathrm{Si}$ interface is evidenced by Fourier transform analysis of Ge K-EXAFS oscillations. Future prospects for in-situ stuctural analysis of epitaxially-grown semiconductor interfaces using a high brilliance synchrotron radiation are discussed.
\end{abstract}

\section{1.はじめに}

最近, MBE, MOCVD 法などのエピタキシ技術の発 達によって，文字どおり1原子着制御が可能になりつつ ある。このような手法を用いた人工格子やへテロ界面の 微視的構造評価では界面の構造を高感度に調べる新しい 構造研究手段が必要である。EXAFS (Extended X-Ray Absorption Fine Structure) はシンクロトロン放射 (SR) 光の利用が実用域 の原子配列を高感度隹調べることができる特徽を利用し て飛躍的な発展を遂げた。EXAFS に関する詳細は総

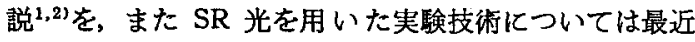
の報告3) 参考にしていただくととにして，本稿では界 面構造への応用として表面敏感 EXAFS 法を中心に最 近の界面構造研究例を釈介する。表面敏感 EXAFS と いう表現は筆者の提案であり定着した名称ではないが， 特任表面 EXAFS と区別する理由は，乙の手法が蛍光 検出法の一種で高い表面感度を有しながら表面から数 $10 \AA$ の深さの界面をむ探ることがでさる点を強調した いためである。界面を調べるためには表面近傍の情報を 選択できなくてはならないが，表面第 1 㜿のみではなく 表面から数原子層あるいは数 10 原子痛潹いところを単 原子層以下の感度で調べるととが要求される。こてでは
表面敏感 EXAFS の原理 および実験法を簡単に説明し た上で幾つかの忘用例を紹介し将来の展望に触れる。

\section{EXAFS および XANES の原理}

\subsection{EXAFS}

Fig. 1 亿 $\mathrm{Si} / \mathrm{Ge} / \mathrm{Si}(100)$ ヘテロ界面の $\mathrm{Ge}-\mathrm{K}$ 蛍光 $\mathrm{X}$ 線収量をフォトンエネルギの関数として示す。11.1 $\mathrm{ke} \cdot \mathrm{V}$ 付近にみられる鋭い立ち上りは $\mathrm{K}$ 殸による吸収端 でそれより高いエネルギ領域に微細構造が観測される。 吸收端付近 (<50 eV) XANES (X-Ray Absorption

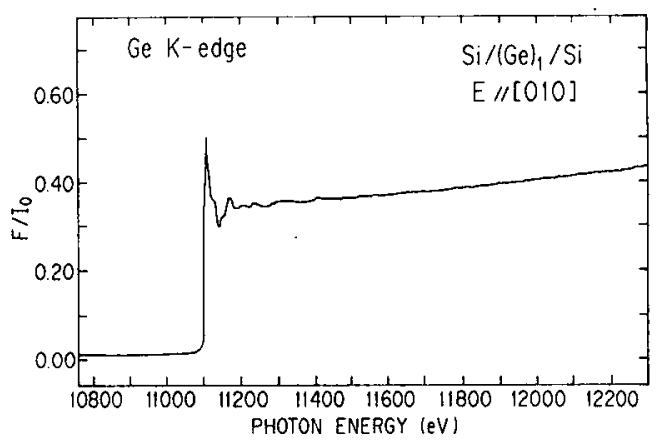

Fig. 1 Ge K-EXAFS spectra for $\left.\mathrm{Si} / \mathrm{Ge} / \mathrm{Si}(100)^{17}\right)$. 


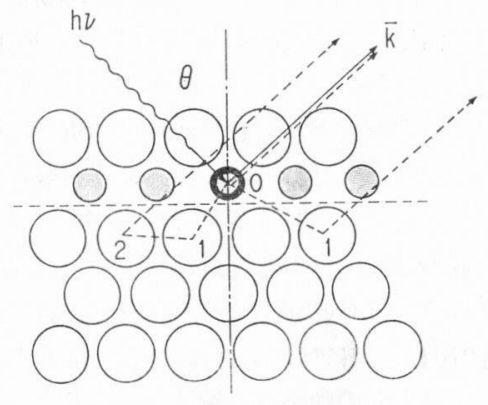

Fig. 2 Principle of surface-sensitive EXAFS.

Near Edge Structure), それより高いエネルギ領域を EXAFS と呼ぶ。EXAFS 領域では光電子の持つ運動エ ネルギは十分大きいので近似的に平面波として报える。

Fig. 2 亿表面敏感 EXAFS の原理を簡単に示す。表面 付近の特定原子を選択的にプローブにするためには特定 のエネルギを持つX線を照射して内殸電子（元素により 異なるエネルギを持つ）を励起する。内殼励起によって 放出される光電子はまわりの原子 $(1,2$ etc $)$ によって散 乱され直接出て行く波之干涉し EXAFS を生じる4。 直接波之散乱波の干涉項は光電子の波数 $k$ について正弦 的な振動を与えるが，その周期から中心原子と散乱原子 の間の距離が，また振幅の大きさから配位原子の種類や 個数が推定できる11。

1 回散乱理論 ${ }^{4)}$ によれば規格化された EXAFS, $\chi(k)$ は次の式であらわされる。

$$
\begin{aligned}
& \chi(k)=-\Sigma S_{0}{ }^{2}\left(N_{\mathrm{i}} / k R_{\mathrm{i}}{ }^{2}\right)\left|f_{1}(k, \pi)\right| \sin \left(2 k R_{\mathrm{i}}\right) \\
&+\Psi_{\mathrm{i}}(k) \times \exp \left(-\sigma_{\mathrm{i}}{ }^{2} k^{2}\right) \exp \left(-R_{\mathrm{i}} / \lambda_{\mathrm{i}}\right) \\
&\left.k=\left[2 \hbar \omega-E_{0}\right)\right]^{1 / 2}
\end{aligned}
$$

ここで $\theta_{\mathrm{i}}$ は電場べクトルと動径ベクトル $R_{\mathrm{i}}$ のなす 角, $\Phi_{\mathrm{i}}(k)$ は光電子の散乱による位相シフト, $N_{\mathrm{i}}, \sigma_{\mathrm{i}}, \lambda_{\mathrm{i}}$ は各々 $\mathrm{i}$ 種散乱原子の配位数, Debye-Waller 因子, 光 電子の平均自由行程である。 $\left|f_{\mathrm{i}}(k, \pi)\right|$ は後方散乱因子 を表す。

\section{2 表面感度を上げた測定法}

通常の EXAFS 測定は遷移確率の変調を吸収量の変 化として観測するため表面に敏感な測定ではない。表面 感度を上げるためには，(1)表面付近から得られる吸収 係数に比例する物理量を測定するか，(2) 表面付近を選 択的に励起する方法が考えられる。前者は脱出樑度の小 さいオージェ電子や 2 次電子などを検出する方式で表面 EXAFS として知られている ${ }^{5,6)}$ 。オージェ電子の脱出 深度は良く知られているように運動エネルギの関数であ るととを利用すれば適当な励起エネルギを選ぶととによ って最も表面感度を上げた測定が可能である。すでにて の方法は $\mathrm{S}, \mathrm{Cl}$ など軟 $\mathrm{X}$ 線領域に吸収端を有する幾つ

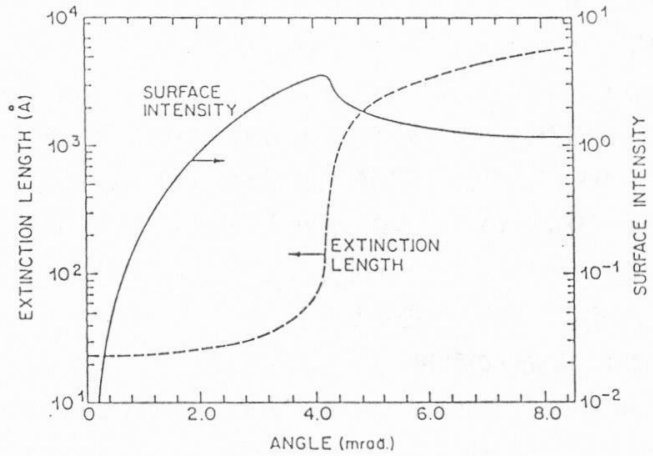

Fig. 3 Angular variation of penetration depth and surface intensity ${ }^{7)}$.

かの原子に対してその有効性が示されており, 吸着原子 サイトや表面での反応の研究に適用されている。しかし 200-800 eV 領域に吸收端を持つ軽原子 $(\mathrm{C}, \mathrm{O}, \mathrm{N}$ etc) で はエネルギ走査によって光電子がオージェ電子のエネル ギに重なる。EXAFS 測定では 500-1000 eV のエネル ギ走査が必要であるためにオージェ電子測定による方法 は測定対象や範囲方限定される。特に $\mathrm{C}, \mathrm{O}, \mathrm{N}$ 原子に ついては 2 次電子検出法が用いられるが, 表面に対する 感度はオージェ電子よりも悪い。

第 2 の方法は表面近傍の原子のみを励起する方法で, このためにはX線の全反射現象を利用するととが考えら れる。入射角を小さくしていくと表面で全反射が起り侵 入距離を数 $10 \AA$ 亿するととができる7)。Fig. 3 亿 Ge を例にフォトンの侵入距離と蛍光X線の表面強度を入射 フォトンの関数として示した。全反射の臨界角付近で侵 入距離が急激に低下することがわかる。表面付近の吸収 分は全反射 X線の強度の極めてわずかな部分を占めるた めに原理的には可能であるが，乙れを直接観測するのは 得策ではない。その代りに励起によって放出される蛍光 X線の収量をモニターすることによって表面付近の蛍光 $\mathrm{EXAFS}^{8)}$ を測定できる。との方法は電子を検出する方 法之異なり試料から蛍光X線の脱出の過程での減衰が無 視できるため界面への適用に便利である。Heald 達によ って全反射法と蛍光 $X$ 線検出法を組み合せた表面敏感な EXAFS 測定法の可能性が示されだ'が，単結晶上の吸 着種や 4.3 節で取り上げるエピタキシャル成長試料への 適用には幾つかの問題を抱えていた。まず第 1 亿 SR 光 ビームの安定性（位置・強度）がある。多くの元素の吸 収端のエネルギは硬 $\mathrm{X}$ 線領域にあるが，X線が全反射す る臨界角は数ミリ $\mathrm{rad}$ である。 SR 光を試料に均一に 照射するには光源の安定性が極めて高い必要がある。次 に試料（主として基板）からのブラッグ反射の問題があ る。これまでの実験は蛍光X線の検出器としてエネルギ 
分解能の低いイオンチェンバー9) やプロポーショナル検 出器 ${ }^{10,11)}$ が使われて来た。この方法では, 特殊な場合 (ブ ラッグ反射が平均化される多結晶 ${ }^{92}$ や軟 X線領域に吸収 端があるためブラッグ反射が起りにくい場合 $\left.{ }^{12)}\right)$ を除い て，単結晶には応用が困難であった。筆者らは最近，エ ネルギ分解能の高い半導体検出器を用いて散乱, 回折に よるバックグラウンドを除くことによって単結晶への適 用が可能であるととを示した。

\section{3 偏光性の利用}

$\mathrm{SR}$ 光の偏光性を考慮すると表面, 界面など異方性の 大きい系では特定方向の動径分布を調べられる。これは EXAFS から 3 次元的情報が得られることを意味してお り，異なる吸着サイトを区別するために利用されてき た。このためには偏光べクトルと試料面のなす角を変え て測定を行なう。全反射条件でこれを行なうためには試
料を入射ビーム方向を軸として回転する必要がある。一 般に硬X線領域では全反射の臨界角は数ミリ $\mathrm{rad}$ 程度 であるが, SR-X 線のビームは水平方向に広くまた発散 も水平方向の方が大きい。したがって SR-X 線の電場 ベクトルが基板に平行な場合に比へ，垂直な場合はビー ム強度の点で全反射実験は不利であるが, 検出器は水平 に置かれるので逆に検出器を試料に充分近い位置に置く ことができる。 $\mathrm{Si} / \mathrm{Ge} / \mathrm{Si}(100)$ 界面の実験では電場べク トルを [010] 方向にほぼ平行にして測定した。これは 基板に平行な方向の動径分布を観測するととになる。

Fig. 4 にO $(2 \times 1) / \mathrm{Cu}(110)$ の O K-偏光 EXAFS と そのフーリエ変換を示す ${ }^{13)}$ 。電場ベクトル $\boldsymbol{E}$ が [001] 方向に平行な場合之垂直な場合でフーリエ変換の絶対值 に大きな差が観測される他，第 4 近接原子によるピーク 位置 (D) は $\boldsymbol{E}$ が [001] に平行な場合には観測されな
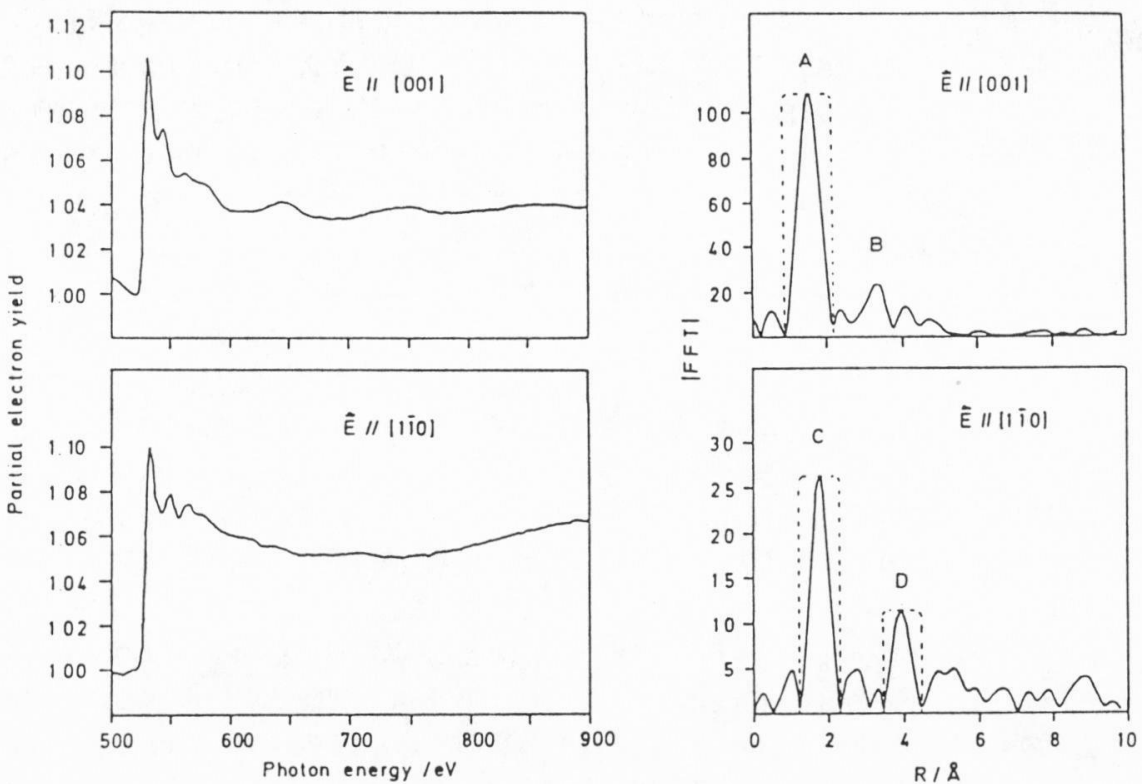

Fig. 4 Polarized K-EXAFS spectra and results of Fourier transform for $\mathrm{O}(2 \times 1) / \mathrm{Cu}(110)^{13)}$.
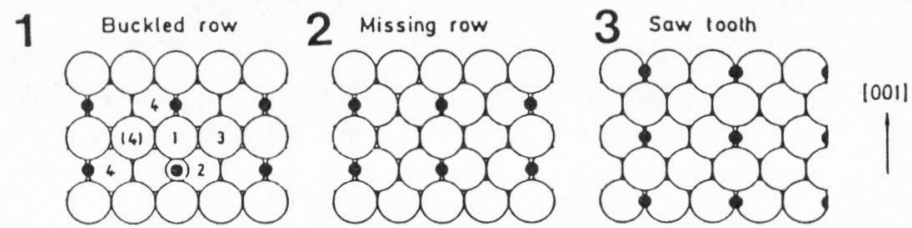

|1io]
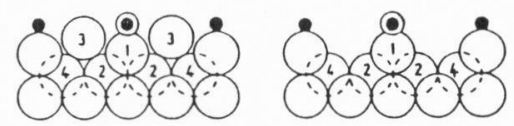

Fig. 5 Structural models for $\mathrm{O}(2 \times 1) / \mathrm{Cu}(110)^{13)}$. 
Table 1 Bond lengths and amplitude ratios for possible model structures for $\mathrm{O}(2 \times 1) / \mathrm{Cu}(110)$.

\begin{tabular}{|c|c|c|c|c|c|c|c|c|}
\hline Azimuth & $\theta /$ degrees & $\begin{array}{c}\mathrm{Cu} \\
\text { neighbor }\end{array}$ & \multicolumn{2}{|c|}{$\begin{array}{l}\text { Experiment } \\
\text { A) } \quad A_{\mathrm{i}} / A_{1}\left(k-4 \AA^{-1}\right)\end{array}$} & $R_{\mathrm{i}}(\AA)$ & $\begin{array}{l}\text { No } \\
\text { reconst- } \\
\text { ruction }\end{array}$ & $\begin{array}{c}\text { Theory } \\
\frac{N_{\mathrm{i}}{ }^{*} / R_{\mathrm{i}}{ }^{2}}{N_{1} * / R_{1}{ }^{2}} \\
\text { Missing row }\end{array}$ & Sawtooth \\
\hline [001] & 90 & 1 & $1.82 \pm 0.02$ & 1 & 1.83 & 1 & 1 & 1 \\
\hline$[1 \overline{1} 0]$ & 90 & 2 & $1.99 \pm 0.02$ & $0.28 \pm 0.01$ & 1. 99 & 0.355 & 0.355 & 0.178 \\
\hline \multirow{4}{*}[1\overline{1}0]{} & \multirow{4}{*}{45} & 3 & $\ldots$ & $\cdots$ & 3. 14 & 0.458 & $\cdots$ & $\ldots$ \\
\hline & & 4 & $4.15 \pm 0.03$ & $0.12 \pm 0.01$ & 4. 16 & 0.354 & 0.354 & 0.251 \\
\hline & & 2 & $1.97 \pm 0.02$ & $0.31 \pm 0.01$ & 1.98 & 0.441 & 0.441 & 0.220 \\
\hline & & 4 & $4.21 \pm 0.05$ & $0.10 \pm 0.03$ & 4.17 & 0.304 & 0.304 & 0.231 \\
\hline
\end{tabular}

い。構造モデルとしては Fig. 5 に示されるような $3 つ$ の場合が考えられる。Table 1 に，これらのモデルを仮 定した場合の電場ベクトルが [001] 方向に平行な時を 基準にした結合距離と振幅の值を示す。これらのモデル の内，第 1 のデルでは第 3 原子位置に $\mathrm{Cu}$ 原子による ピークが観測されるはずであるが，このピークはみられ ない。残る 2 つのデルでは第 2 近接原子以降の原子に 対して振幅に差が現われる。絶対值の一致は良くないが 第 2 の構造モデルの方が実験と良く合う。偏光依存性は このように 3 次元構造の知見を得るのに重要な手段であ るが, SR 光の偏光性は極めて高いので表面構造研究に 有効である。

\subsection{XANES}

吸収端から約 $50 \mathrm{eV}$ の領域 XANES は伝導帯への 遷移と考えることができ, 吸収原子の価数状態や吸収原 子のまわりの立体配位に関する情報が得られる。Fig. 6 にSi/Ge/Si(100) ヘテロ界面の Ge K-XANES スペク トルを示す。一般に XANES 領域は鋭い構造を持つの で EXAFS 領域に比べて高分解能で測定する必要があ る。XANES 領域の理論的取り扱いは EXAFS に比へ て繁雑であるためまだ完全に確立したわけではない。一

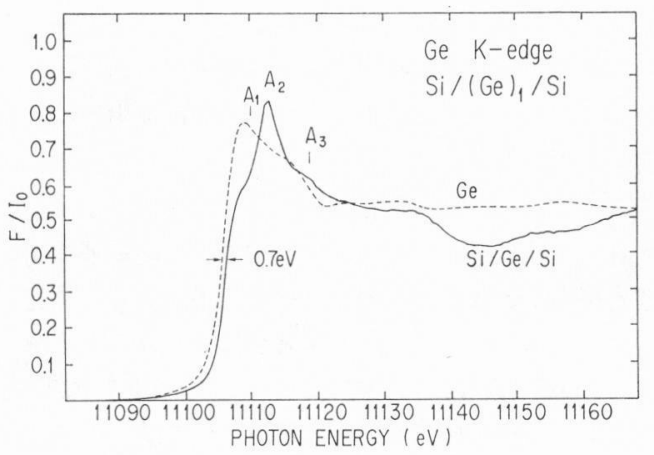

Fig. 6 Ge K XANES spectra for $\mathrm{Si} / \mathrm{Ge} / \mathrm{Si}(100)$ and $\mathrm{c}-\mathrm{Ge}^{17)}$.

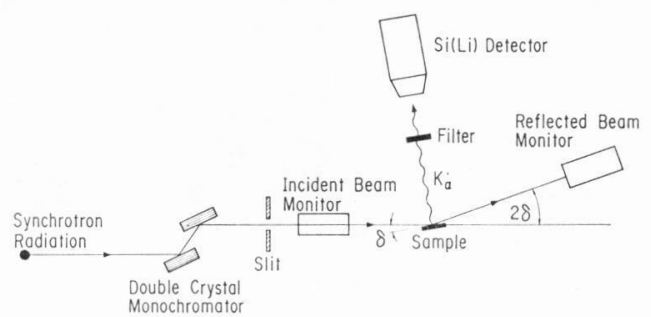

Fig. 7 Experimental set-up for surface-sensitive EXAFS.

般に高価数状態ほど吸収端のエネルギは高い方にシフ トすることが知られている。Fig 6 亿示されるように

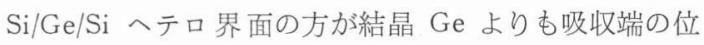
置が高エネルギ側にあり, 吸収端極大付近の微細構造 $\left(\mathrm{A}_{1}-\mathrm{A}_{3}\right)$ あ大きく変化する。

\section{3. 表面敏感 EXAFS の実験法}

Fig. 7 に表面敏感 EXAFS の実験系の概略を示した。 $\mathrm{SR}$ 光はむともと角度拡がりが極めて小さいため高輝 度ではあるが，単原子層以下の検出感度を達成するには さらに収束X線光学系により輝度を上げる必要がある。 Fig. 7 の例では湾曲 2 結晶分光器により SR 光を単色 化すると同時に水平方向に収束してビームの輝度を上げ ている。蓄積リングが $2.5 \mathrm{GeV}$ で運転されている時ビ 一ム強度は $10^{10}$ フォトン/秒以上が得られている。試 料からの蛍光X線を計測するためには広い立体角にわた って検出するためにこれまで多数の検出器を並べたりイ オンチェンバーのように大きな有効面積を持つ検出器が 用いられる。筆者らは基板からのブラッグ反射による妨 害を最小限に押える目的で 18 個のシンチレーション検 出器および半導体検出器 1 台から成る多素子検出器シス テム ${ }^{14)}$ を開発した。このシステムは数 $100 \AA$ 以上の薄 膜に対しては十分効率の良い実験が可能であることを確 認したが， 1 原子層レベルでへテロ界面を調べるために 


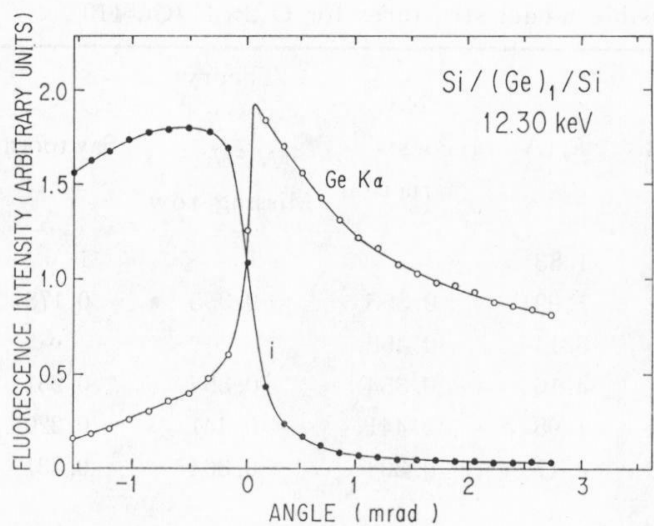

Fig. 8 Angular variation of fluorescence and reflected beam intensity for $\mathrm{Si} / \mathrm{Ge} / \mathrm{Si}(100)^{17}$.

は表面感度をさらに上げる必要がある。筆者らはこのた めに全反射を利用して表面感度を上げたうえで半導体検 出器と波高分析により蛍光X線のみを計測する方法を用 いている。表面敏感 EXAFS 法が界面構造研究手段とし ての特徽は, (1)高い信号対雑音比を持っているとと, (2)界面からの信号が減衰せずに検出できるとと, (3) 深さ方向の分析領域が制御できるととなどである。

\section{4. 表面敏感 EXAFS の応用例}

\section{1 全反射と蛍光 $\mathrm{X}$ 線強度の関係}

Fig. 8 亿 Si $/ \mathrm{Ge} / \mathrm{Si}(100)$ へテロ界面試料について测 定されたX線入射角と反射率と蛍光 $X$ 線の関係を示す。 白丸，黒丸はそれぞれ $\mathrm{Ge} K$ 蛍光 X線および反射 $X$ 線 の強度を示す。入射角を小さくしていくと蛍光X線強度 は増大していくが全反射領域で急激に減少する。全反射 の臨界角は基板の密度によって決るが $\mathrm{Si}$ の場合 $\mathrm{GeK}$ 吸収端のエネルギ $(11.1 \mathrm{keV})$ では 3.5 ミリ $\mathrm{rad}$ 程度 である。全反射領域では散乱強度が大幅に減少するので 相対的に信号対雑音比は増大し表面感度が向上する。全 反射領域では, X線の強度は急激に減衰するので侵入樑 さは数 $10 \AA$ 程度となるが, 硬X線領域ではX線の侵入 深さは数 $10 \mu$ 程度であるから全反射領域では表面感度 は実質的に $10^{3}$ 程度向上する。Fig. 1, 4 亿示すように全 反射領域では高い信号対雑音比でスペクトルが得られて いる。ブラッグ反射の問題のないガラス基板や多結晶の 場合は検出器としてエネルギ分解能の悪いシンチレーシ ョン検出器, イオンチェンバ, プロポーショナル検出器 などを半導体検出器の代りに用いることができる。一般 には 4.2 節で紹介する特殊な場合（軟 X線領域）を除い て単結晶への適用は困難であった。

\section{2 オージェ電子法との比較}

Fig. 9 にオージェ電子收量および蛍光収量をモニタ

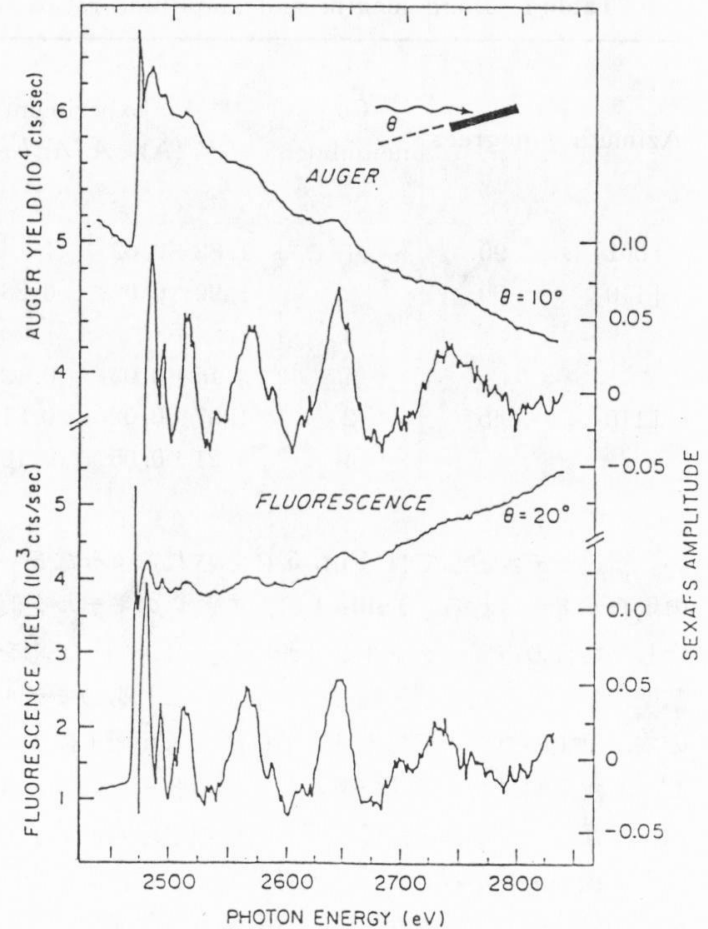

Fig. $9 \mathrm{~S}$ K-EXAFS spectra measured by fluorescence and Auger detection modes ${ }^{11}$.

一するととにより得られた $\mathrm{Ni}$ 上に吸着した $\mathrm{S}$ 原子の SK-EXAFS スペクトルを示す。SK 吸収端は 2.3 $\mathrm{keV}$ にあるためこのエネルギではブラッグ反射は起と りにくい。また $\mathrm{Ni}$ の L蛍光X線は $1 \mathrm{keV}$ 以下である ので途中の Be 空により吸収されて問題にならないの で, エネルギ分解能の低いプロポーショナル検出器でも オージェ電子法に比べて信号対雑音比の良いスペクトル が得られている。この例では入射 X線が試料となす角度 は 20 度で全反射条件ではないが，上述の理由により十 分質の良いスペクトルが得られている。オージェ電子の 測定には CMA (Cylindrical Mirror Analyzer) を用 いるが試料を見込む立体角は極めて小さい。Fig，10 亿 CMA を用いる測定系 ${ }^{15)}$ を示す。蛍光X線の検出器とし て $\mathrm{Si}(\mathrm{Li})$ あるいは純 $\mathrm{Ge}$ などの半導体検出器を用いる 場合, 原理的には検出器を試料の近くに置くととによっ て試料を見込む立体角をかせぐことができるが，実際に は信号増幅の過程で計数率が制限されるので多検出素子 方式が必要となろう。現状では 1 原子層からの蛍光 $X$ 線 は 5-6 $\times 10^{3} \mathrm{cps}$ で, 数え落しが無視できる強度でもあ る。しかしこれは垂直方向にビームを収束しない場合 で，集光ミラーなどの光学素子によってビームを垂直方 向にも收束すれば数 10 倍強度は増大し検出器側の計数 効率を改善することが必要となる。 


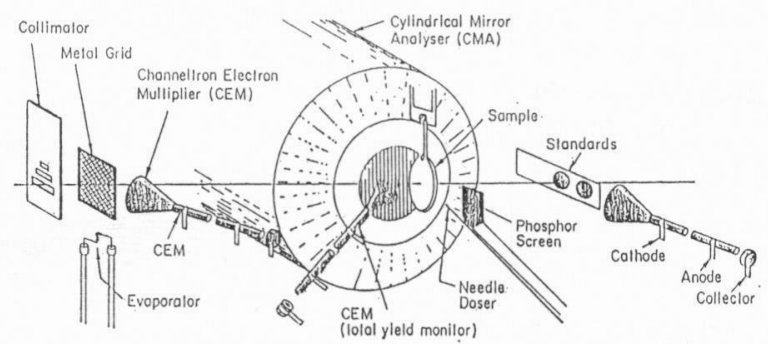

Fig. 10 Surface EXAFS experimental set-up by Auger detection mode ${ }^{15)}$.

\section{$4.3 \mathrm{Si} / \mathrm{Ge} / \mathrm{Si}$ 界面構造}

最近, MBE によるエピタキシャル成長中の RHEED 強度にみられる振動を用いた 1 原子層制御を行なう試み が報告されている16)。坂本らは RHEED 振動を用いた $\mathrm{GeSi} / \mathrm{Si}$ 超格子の $\mathrm{MBE}$ 成長を試みている。とてでは $\mathrm{Si}(100)$ 基板上に $\mathrm{Si} / \mathrm{Ge} / \mathrm{Si}$ ヘテロ界面を RHEED 振 動を用いて MBE 成長させ, Ge をプローブとして界面 構造を調べた結果について述べる ${ }^{17)}$ 。基板として良く配 向した $\mathrm{p}$ 型 $\mathrm{Si}(100)$ を用いた。 $800^{\circ} \mathrm{C}$ での加熱により酸 化膜を取りのぞいた後, アンドープのバッファ層 $(2,000$ $\AA$ ）を $500^{\circ} \mathrm{C}$ で成長させた。 $1,000^{\circ} \mathrm{C}$ で 20 分加熱する ととにより単一ドメインの $\mathrm{Si}(100) 2 \times 1$ 構造を得た。 1 原子層レベルでの $\mathrm{Ge}, \mathrm{Si}$ 制御は RHEED スポット の強度をモニターするととにより行った。Fig. 11 に $\mathrm{Ge}(\mathrm{Si})$ 成長時の RHEED 強度変化を示す。RHEEED スポット強度の最大值が $1 \mathrm{ML}$ 亿相当する。 $\mathrm{Si}(100)$ 上 に $\mathrm{Ge}$ を 1 原子層成長させた後, さらに $\mathrm{Si}$ を 22 層成 長させた。

試料 $(15 \mathrm{~mm} \times 10 \mathrm{~mm})$ を精密ステージで縦方向に細 く絞ったX線ビームに照射して, $\mathrm{Si}(\mathrm{Li})$ 検出器により Ge K $\alpha$ X 線を計測して EXAFS を测定した。すでに述

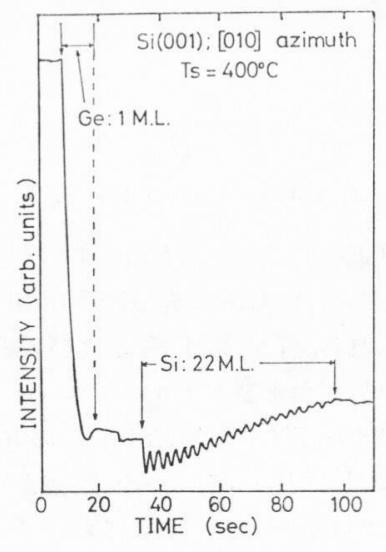

Fig. 11 RHEED intensity oscillation during the growth of $\mathrm{Si} / \mathrm{Ge} / \mathrm{Si}(100)^{17}$.

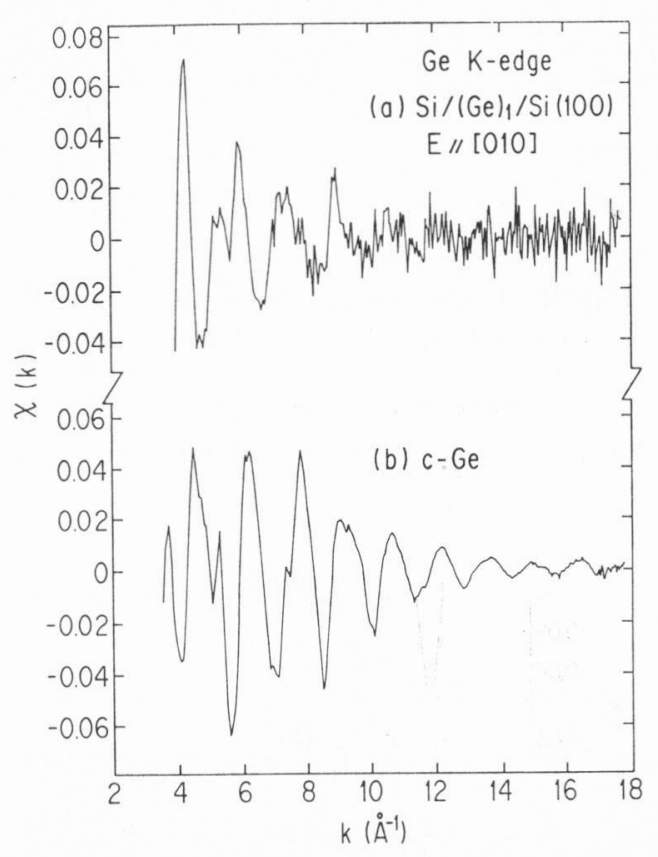

Fig. 12 Ge K-EXAFS oscillations for $\mathrm{Si} / \mathrm{Ge} /$ $\mathrm{Si}(100)$ and $\mathrm{c}-\mathrm{Ge}^{17)}$.

ベたようにX線全反射の臨界角はエネルギに依存する。 EXAFS の測定では $1,000 \mathrm{eV}$ 以上の領域にわたるので スペクトル全体が全反射条件を満足するように, 最大エ ネルギ $(12.3 \mathrm{keV})$ で入射角を決定した。Fig. 12 に 得られたスペクトルを示す。この図に示されるように高 エネルギ分解能の検出器を用いるととにより高い信号対 雑音比 (60-70) でスペクトルが得られる。ただし現状 では半導体検出器の有効面積および計数速度によってス ペクトルを得るのに 10-11 時間を要している。

このスペクトルから EXAFS の振動部分を抜きだし てその $k$ 依存性を調べると $\mathrm{Ge}$ 原子之結合している原子 種が推定できる。Fig. 12(a) に $\mathrm{Si} / \mathrm{Ge} / \mathrm{Si}(100)$ ヘテロ 界面の Ge K-EXAFS を, (b)に透過法で測定された結 晶 $\mathrm{Ge}$ の GeK-EXAFS を示す。(a)では振幅が光電 


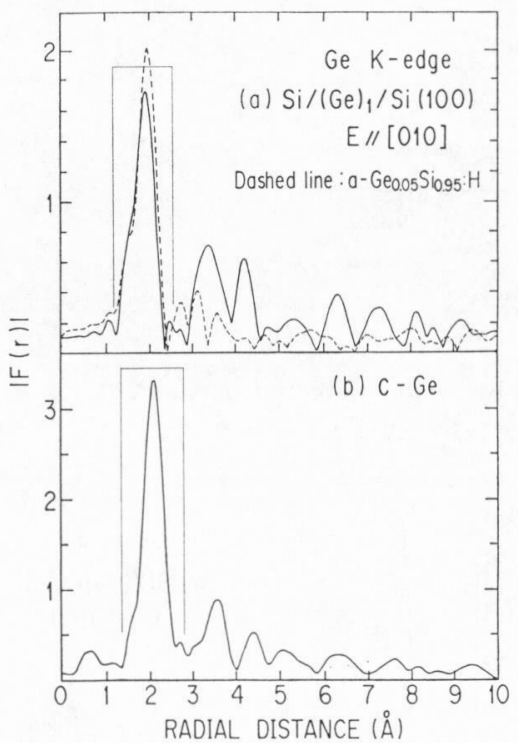

Fig. 13 Results of Fourier transform of $\mathrm{Ge}$ $\mathrm{K}-\mathrm{EXAFS}$ for $\mathrm{Si} / \mathrm{Ge} / \mathrm{Si}(100)$ and $\mathrm{c}-\mathrm{Ge}^{177}$.

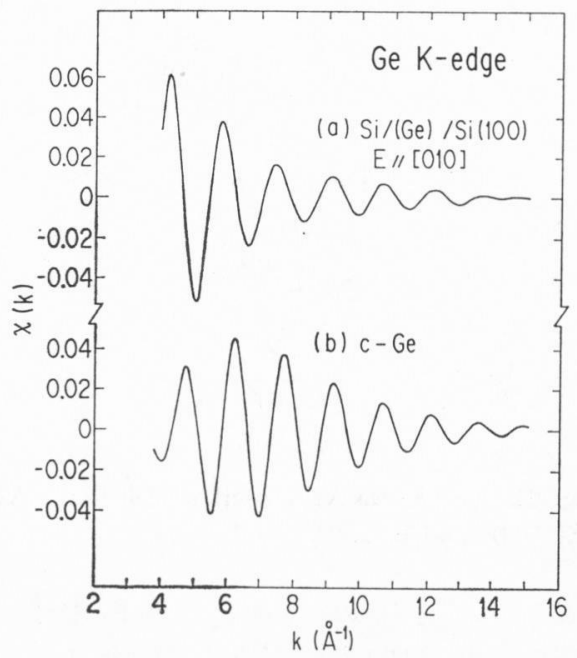

Fig. 14 First shell Ge K-EXAFS oscillations for $\mathrm{Si} / \mathrm{Ge} / \mathrm{Si}(100)$ and $\mathrm{c}-\mathrm{Ge}^{17}$.

子の波数 $k$ に対して単調に減衰しているが，(b)では $k=6-8 \AA$ 亿極大值を持ち $k=15-16 \AA^{-1}$ の領域までゆ るやかに減少している。EXAFS の振幅の $k$ 依存性は 原子の種類によって異なる。(a), ( b ) における EXAFS 振幅の $k$ 依存性は各々 $\mathrm{Si}, \mathrm{Ge}$ 原子に特有な後方散乱振 幅で説明できることから，(a) では Ge 原子が $\mathrm{Si} と$ 結合しているとと即ち $\mathrm{Ge}$ 原子が $\mathrm{Ge}$ クラスターを形 成していないととを意味する。Fig. 13 K Fig. 9 のデ 一タをフーリエ変換した結果を示す。 $2 \AA$ 付近に観測さ れるピークは第 1 近接原子による。 $3-4 \AA$ 付近のピーク

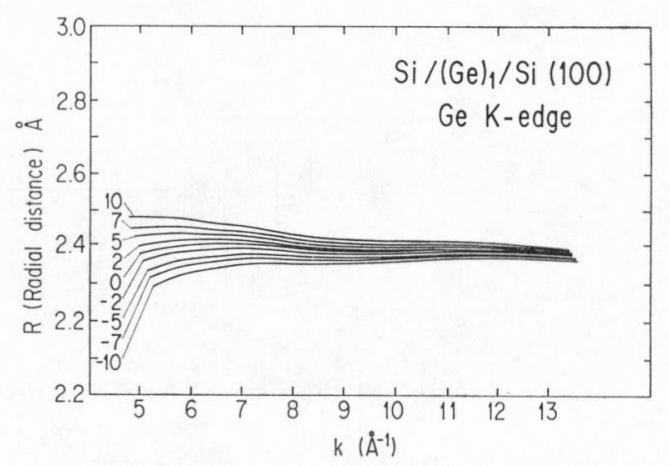

Fig. 15 Radial distance as a function of $k$ for various $E_{\text {n }}$ values ${ }^{17)}$.

Table 2 Determined interatomic distances for $\mathrm{Si} / \mathrm{Ge} / \mathrm{Si}(100)$ heterostructure.

\begin{tabular}{l|ll}
\hline \multicolumn{1}{c|}{ Specimen } & \multicolumn{2}{|c}{ Interatomic distance $(\AA)$} \\
\hline $\mathrm{Si} / \mathrm{Ge} / \mathrm{Si}$ on $\mathrm{Si}(100)$ & $\mathrm{Ge}-\mathrm{Si}$ & $2.378(2)$ \\
a-Ge.05 $\mathrm{Si} 0.95: \mathrm{H}$ & $\mathrm{Ge}-\mathrm{Si}$ & $2.404(2)$ \\
Crystalline Ge & $\mathrm{Ge}-\mathrm{Ge}$ & $2.450^{*}$ \\
Crystalline Si & $\mathrm{Si}-\mathrm{Si}$ & $2.350^{*}$
\end{tabular}

* Determined by X-ray diffraction.

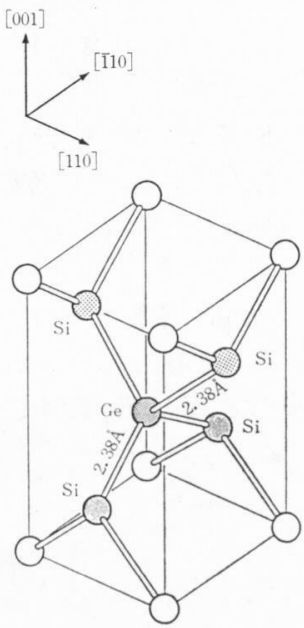

Fig. 16 Structural model for $\mathrm{Si} / \mathrm{Ge} / \mathrm{Si}(100)$.

は第 2 , 第 3 近接原子によるものであるが, これらが観 測されるととから $\mathrm{Si} / \mathrm{Ge} / \mathrm{Si}$ 界面は秩序相をつくって いると考えられる。(a )の実線および点線は $\mathrm{Si} / \mathrm{Ge} / \mathrm{Si}$ (100) へテロ界面打よびアモルファス $\mathrm{Ge}_{0.05} \mathrm{Si}_{0.95}$ : H についての結果を示す。 $\mathrm{Si} / \mathrm{Ge} / \mathrm{Si}$ 試料の方がアモルフ アス $\mathrm{Ge}-\mathrm{Si}: \mathrm{H}$ に比べて Ge-Si 距離が短いととはこ の図から明らかであるが, 正確にてれを求めるために 枠で囲まれた部分を $k$ 空間に逆にフーリエ変換した。

Fig. 14 にその結果を示す。とのような EXAFS 振動 


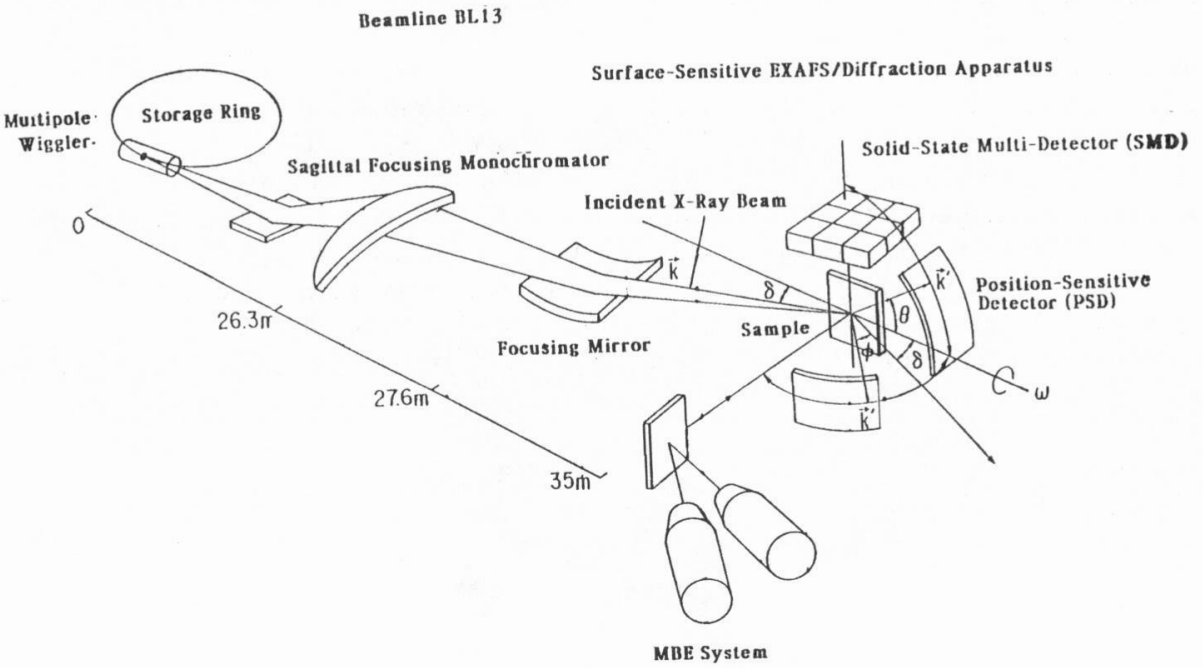

Fig. 17 Schematic of surface-sensitive stractural analysis utilizing high brilliance synchrotron radiation.

の周期は $2 k R(R$ は結合距離を意味する) と散乱の位 相シフトから成る。散乱の位相シフトは中心原子と散乱 原子の組合せにより異なるが，ととでは理論計算による 值を用いて補正した。

Fig. 15 にエネルギ原点を調節するためのパラメータ $E_{0}(\mathrm{eV})$ を変化させた時の $\mathrm{Ge}-\mathrm{Si}$ 結合距離 $R$ の $k$ 依 存性を示す。 $k$ について $R$ の傾きが最む小さくなるよ うに $E_{0}$ を選んで Ge-Si 距離を求めた結果を Table 2 に示す。この結果から $\mathrm{Si} / \mathrm{Ge} / \mathrm{Si}$ 界面の $\mathrm{Ge}$-Si 距離は $2.38 \AA$ となり $\mathrm{Ge}, \mathrm{Si}$ 原子の共有結合半径の和よりも 小さい。一方アモルファス Ge-Si : H では Ge-Si 距 離がほぼ共有結合半径の和に等しい。

Fig. 16 に Si/Ge/Si(100) の構造を模式的に示す。 $\mathrm{Ge}-\mathrm{Si}$ 距離がバルク $\mathrm{Si}$ における $\mathrm{Si}-\mathrm{Si}$ 距離に近い。 このととは $\mathrm{Si} / \mathrm{Ge} / \mathrm{Si}$ 界面における格子緩和が通常の泥 晶や歪超格子とは異なり, 結合角よりも結合距離による 寄与が大きいことを示唆している。したがって Si/Ge/ $\mathrm{Si}$ 界面では格子整合が正方的な歪よりむしろ静水圧的 な圧縮の効果を引き起していると考えられる。最近, へ テロ界面の構造緩和がバンド構造に及ぼす効果を考察す る時は結合距離の緩和が無視できないととが報告され ている ${ }^{18)}$ 。

\section{5.おわりに}

現在, SR-X 線を水平方向に収束するととにより単 原子層以下の検出感度が得られているが, ビーム強度が 不足であることと検出効率が悪いために測定に長時間を 要している。今後は多極ウィグラーの利用や垂直方向の
収束を合せて行なうなど，収束 X線光学系の改良や検出 器の高効率化によって検出感度は改善される。筆者らは 現在 29 極ウィグラーを光源とし, 半導体多素子検出器 を開発することによりこれまでより 2 桁感度を増大させ る試みを行っている ${ }^{19)}$ 。Fig. 17 に高輝度 SR-X 線を用 いたその場構造解析装置の概略を示す。この装置には $\mathrm{Si}$ (Li) 素子を 7 個同心円状に配置した超高真空仕様の 半導体多素子検出器が組み込まれる。またこの装置には $\mathrm{MBE}$ などの試料成長が超高真空分析チェンバーに接続 される。このようなその場構造解析装置を用いて, 1 原 子層制御による人工格子材料の構造を成長過程でその場 分析するととが可能になるあのと考えられる。

\section{文献}

1) P. A. Lee, P. H. Citrin, P. Eisenberger and B. M. Kincaid: Rev. Mod. Phys. 53, 769 (1981).

2) 細谷資明, 川村隆明, 深町共栄: 応用物理 47 , 708. (1978).

3) 大柳宏之, 松下 正: 応用物理 53, 307 (1984).

4) E. A. Stern: Phys. Rev. B 10, 3027 (1974).

5) J. Stohr, L. I. Johansson, S. Brennan, M. Hecht and J. Miller: Phys. Rev. B 22, 409 (1980).

6) J. Stohr and R. Jaeger: Phys. Rev. B 26, 4111 (1982).

7) R.S. Becker, J. A. Golovchenko and J. R. Patel: Phys. Rev. Lett. 50, 153 (1983).

8) J. Jaklevic, J. A. Kirby, M. P. Klein, A.S. Robertson, G.S. Brown and P. Eisenberger: Solid State Commun. 23, 679 (1977).

9) S. M. Heald, E. Keller and E. A. Stern: Physics Lett. 103A, 155 (1984). 
10) B. Lairson, T. N. Rhodin and W. Ho: Solid State Commun. 55, 925 (1985).

11) J. Stohr, E. B. Kollin, D. A. Fischer, J. B. Hastings, F. Zaera and F. Sette: Phys. Rev. Lett. 55, 1468 (1985).

12) J. Stohr, L. I. Johansson, S. Brennan, M. Hecht and J. Miller: Phys. Rev. B22, 4052 (1980).

13) M. Baber, A. Puschmann, C. Ocal and J. Haase: Phys. Rev. B 5, 3273 (1988).

14) H. Oyanagi, T. Matsushita, H. Tanoue, T. Ishiguro and K. Kohra: Jpn. J. Appl. Phys. 24, 502 (1985).
15) J. Stohr and R. Jaeger: Phys. Rev. B 26, 4111 (1982).

16) T. Sakamoto, N. J. Kawai, T. Nakagawa, K. Ohta and T. Kojima: Appl. Phys. Lett. 47, 617 (1985).

17) H. Oyanagi, T. Sakamoto, K. Sakamoto, T. Matsushita, T. Yao and T. Ishiguro: J. Phys. Soc. Jpn. 57, 2086 (1988).

18) S. Froyen, D. M. Wood and A. Zunger : Phys. Rev. B36, 36 (1987).

19）科学技術庁振興調整費に基づく研究. 